Int. J. Morphol.,

32(2):399-403, 2014

\title{
Multidisciplinary Approach in the Teaching of Dental Sculpture and Anatomy
}

\author{
Enfoque Multidisciplinario para la Enseñanza de Escultura y Anatomía Dental
}

\begin{abstract}
Rogério Leone Buchaim*; Jesus Carlos Andreo*; Antonio de Castro Rodrigues*; Jéssica Barbosa de Oliveira Gonçalves*; Letícia Rossi Daré*; Geraldo Marco Rosa Júnior**; Daniela Vieira Buchaim**** \& José Américo de Oliveira*****
\end{abstract}

\begin{abstract}
BUCHAIM, R. L.; ANDREO, J. C.; RODRIGUES, A. C.; GONÇALVES, J. B. O.; DARÉ, L. R.; ROSA JÚNIOR, G. M.; BUCHAIM, D. V. \& DE OLIVEIRA, J. A. Multidisciplinary approach in the teaching of dental sculpture and anatomy. Int. J. Morphol., 32(2):399-403, 2014.
\end{abstract}

SUMMARY: The purpose of the Dental Sculpture and Anatomy discipline is to introduce undergraduate students to the study of the anatomic and morphological characteristics of permanent and primary human dentition, through classes, books and cognitive and psychomotor activities. This discipline supports the teaching of specific knowledge necessary for a more extensive education, involving interdisciplinarity as a means of knowledge exchange among several areas of dentistry, to achieve comprehensive professional education. Students must recognize the dental morphology from samples of preserved teeth, and reproduce the morphology through three-dimensional models made of stone or wax blocks. In this article, the authors describe the process for producing teeth collars and macro dental models made of stone, their importance and benefits of utilization. The purpose of the study was to encourage the teaching of Dental Sculpture and Anatomy toundergraduate students of the Bauru School of Dentistry, University of São Paulo, through activities that would associate theory, practice and the development of manual skills.

KEY WORDS: Dental anatomy; Education methods; Undergraduate students; Basic sciences.

\section{INTRODUCTION}

The Dental anatomy discipline is a component of the basic sciences in the program of Dentistry Schools and introduces students to the morphological characteristics of primary and permanent human dentition. The learning process is based mainly on the identification of natural teeth and on the study of stone or resin macro models made by anatomy laboratory technicians (Stewart et al., 1989; Gleiser, 1992; Siéssere et al., 2005). Thus, students learn how to identify different teeth and recognize possible abnormalities (Stewart et al., 1989; Gleiser, 1992; Siéssere et al., 2005; Obrez et al., 2011).

Typically, the content is taught using books, booklets, course manuals and through theoretical classes. Students most often play a passive role in the learning process (Adams, 1976; Jiffry et al., 1987). The performance evaluation is unilateral and subjective, revealing weaknesses of the method, which is exclusively theoretical (Mitov et al., 2010; Durham et al., 2009; Peck \& Skandalakis, 2004).
Traditional classes suffer with the lack of possibilities for interaction, as they do not develop manual skills (Pao et al., 1984; Kataoka et al., 2005). Furthermore, several teaching institutions, with the purpose of developing psychomotor skills, have associated these classes with the activity of recognizing and reproducing dental morphology by examining samples of preserved teeth combined with the dental sculpture from wax blocks (Brueckner \& MacPherson, 2004; Siéssere et al.). In other institutions, dental anatomy classes are associated with programs to restore carious teeth using composite resin (Allen \& McAndrew, 2004).

New methodologies include using videos as a tool to teach anatomy, which, with the advantage of the general public access to the Internet, disseminate anatomy education across worldwide video sharing networks (e.g. YouTube) (Saxena et al., 2008; Jaffar, 2012).

The Brazilian National Curriculum Guidelines for

\footnotetext{
Department of Biological Sciences (Anatomy), Bauru School of Dentistry, University of São Paulo (FOB/USP), Bauru-SP, Brazil.

** Anatomy, Sacred Heart University (USC), Bauru-SP, Brazil.

*** Anatomy, University of Marília (UNIMAR), Marília-SP, Brazil.

***** Department of Basic Sciences (Anatomy), Araçatuba School of Dentistry, São Paulo State University (FOA/UNESP), Araçatuba-SP, Brazil.
} 
Dentistry Education determines that the general purpose of the course must define the profile of the students, involving the cognitive, emotional and psychomotor dimensions (Morita et al., 2007). The course must also approach and integrate basic knowledge with clinical practice, make the curricular integration feasible and use teaching/learning methodologies that allow students to participate in this process (Allen \& McAndrew).

This integration between basic sciences and clinical disciplines is an important link between theory and practice, and has been a trend seen over the last 10 to 15 years, thus being an effective teaching element (Valachovic, 1997; Fiehn, 1998; Bogacki et al., 2004; Scheven, 2012).

Aimed at achieving this integration, the Bauru School of Dentistry, University of São Paulo, Brazil (FOB-USP) has included the Dental Sculpture and Anatomy discipline in its curriculum, which involves multiple departments, and develops research and teaching methodologies that includes the association between theory and practice.

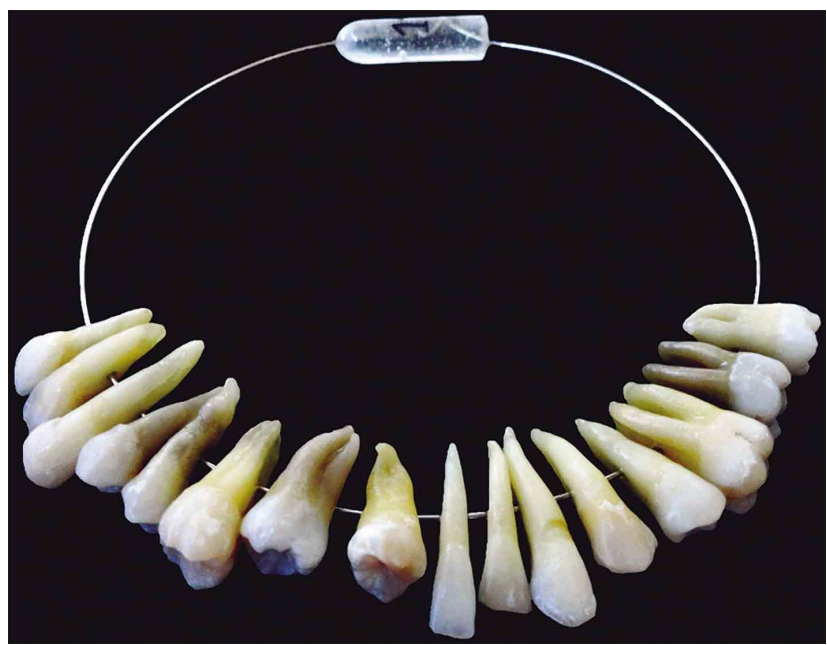

Fig. 1. A manufactured collar containing these dental elements, which does not necessarily contain teeth of one same hemiarch.
In order to promote this association through practical integrative activities, the present study aimed at modifying the emphasis of the decontextualized learning technique to a more active and clinically applicable learning technique, using a multidisciplinary method with the manufacture of macromodels and teeth collars by the students.

\section{MATERIAL AND METHOD}

Manufacturing teeth collars. Natural human teeth were obtained from the teeth bank of the anatomy discipline of the Bauru School of Dentistry. Thirty samples of each tooth were used. The students identified the teeth and separated them into dental groups and according to dental notation. Subsequently, the teeth were washed in running water for 24 hours, kept in hydrogen peroxide 10 volume diluted to $4 \%$ for the same period, washed in running water for another 12 hours, and then scraped with periodontal curettes.

After drying, the carious tissue was removed and the restoration was performed with light-cured composite resin, recovering the original anatomy of the healthy tooth. After finishing and polishing the restoration, the roots were perforated for the final assembly of the 30 collars, which had a $1.0 \mathrm{~mm}$ orthodontic steel wire passing through the opening, which was sealed with self-curing acrylic resin (Fig. 1).

Manufacturing the macromodels. Intact anatomic details were considered for the anatomic reconstruction, without damages caused by occlusion, abrasion, erosion or attrition. A first upper molar tooth and a first lower molar tooth were waxed and sculpted (in utility wax) with a Le Cron and Hollenback $3 \mathrm{~S}$ spatula. The tooth was placed into a compressed air system, and, through pressure, the silicon mold was obtained using Bluesil RTV 3040 A (Blue Star Silicones, Fig. 2A).
Fig. 2. A. Silicon mold used in this work; and B. stone model without anatomic details painted.

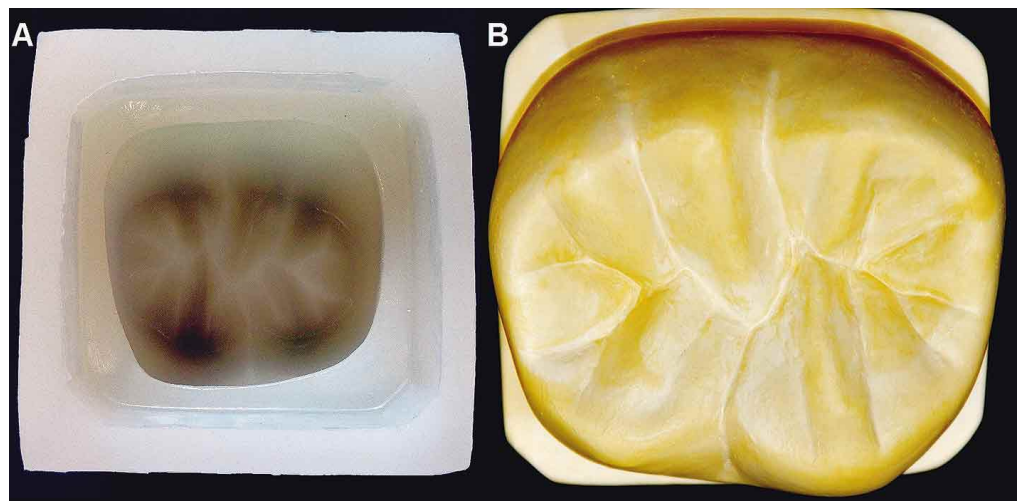


The stone macromodels were obtained by filling the silicon molds with stone. After completing the stone press period, the models were removed from the molds (Fig. 2B).

Five models were obtained for each previously sculpted dental element. The anatomic details were painted using different shades of acrylic paint for a detailed representation of the dental anatomy. After the painting, all models were varnished (Figs. 3A and 3B).

\section{RESULTS}

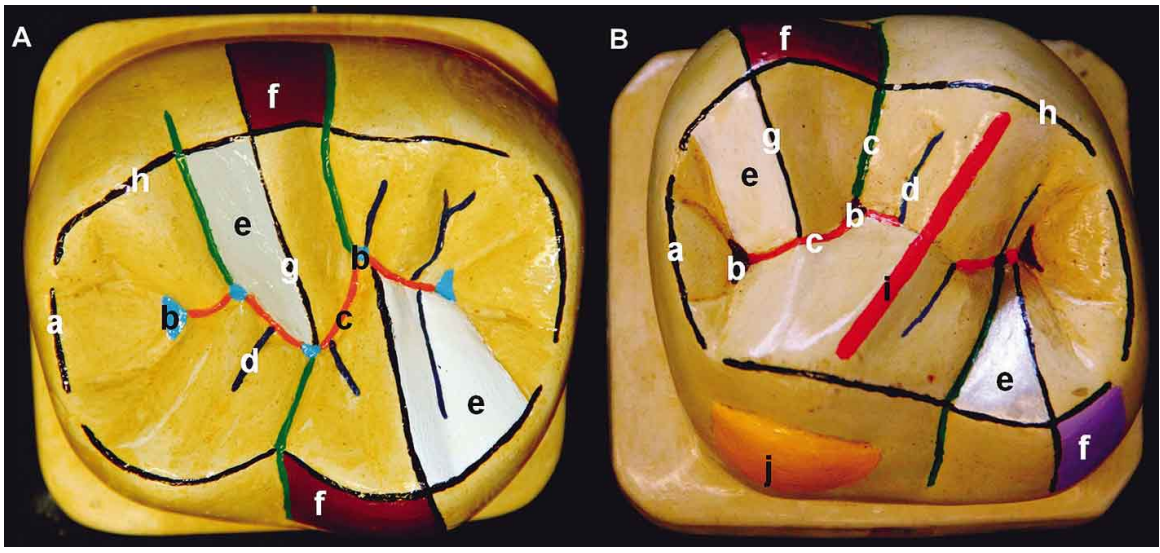

Fig. 3. A and B - Stone models with anatomic details painted: a. marginal ridge; b. main pit; c. developmental groove; d. supplemental groove; e. grinding side; f. smooth side; g. transverse ridge; h. longitudinal ridge; i. oblique ridge; j. tubercle of Carabelli.
In order to promote integrative practices in the Dentistry Course, the present study promotes a more active and clinically applicable learning technique using a multidisciplinary method that involved students manufacturing teeth macromodels and collars.

A total of 30 collars were made, containing one sample of each tooth. Each set of materials is used by a pair of first year dental students, during the practical classes of Dental Sculpture and Anatomy at FOB-USP, aimed at teaching and learning the characteristics of the dental anatomic structures.

Five macromodels were made of the first upper molar, and another five macromodels of the first lower molar tooth. This material is also used in the practical Dental Sculpture and Anatomy classes at FOB-USP, besides being a part of the institution's anatomy museum collection.

The educational material promoted among students, not only the development of essential manual skills for the profession as dentists, but also the curricular integration of basic and clinical disciplines. The collars and models are facilitating teaching methods which together in association with other activities (participative theoretical classes, seminars, sculpture, drawing and others), contribute to the proper qualification of the dentist.

\section{DISCUSSION}

The authors expected this study would create a means to connect basic and professional disciplines, through integrative curricular activities that would allow for more active and clinically applicable learning to take place, through the students manufacturing of macromodels and teeth collars.

This activity promoted a greater development of the students' manual skills and facilitated the learning of Dental Sculpture and Anatomy.

In the health area courses, there must always be a connection between clinical practice and basic sciences, which constitute the true foundation in the program and in the dental education (Adams). Several Higher Education Institutions and Dentistry Class Associations confirmed, mainly through questionnaires, the importance that must be given to the basic sciences (Stewart et al.). Those questionnaires consisted of the teaching methods, including information on the integration between the disciplines of basic sciences and those of clinical teaching (Fiehn).

Dental Sculpture and Anatomy comprise part of the referred basic sciences, and ideally anatomy professors should be health professionals who consistently use anatomy in their daily practices (Peck \& Skandalakis).

It is possible to observe that a global effort has been made to seek alternative and/or auxiliary teaching methods aimed at greater interdisciplinarity. Harvard University drastically changed, their teaching strategies twice, considering this issue (Valachovic).

In the search for innovative methodologies, one of the current effective tools being used to teach anatomy is the online social network of video sharing (e.g. YouTube) 
(Jaffar). Also using the Internet, other tools involve knowledge methods based on programs such as MorphoDent, in which students may have online access to human teeth models in 3D, achieving a more detailed study of morphology (Mitov et al.); and Tooth Morphology, which uses texts, photographs, illustrations and virtual lectures to teach dental morphology (Bogacki et al.). The one unfortunate aspect is that these virtual methods do not develop manual skills.

Pilot projects using composite resin for the replication of human teeth are also used as an integrative methodology, thus creating a link between Dental Anatomy and the restoring clinical part (Allen \& McAndrew). The use of wax to restore the teeth of acrylic resin mannequins is also an educational method, which also stimulates cognitive and psychomotor skills of the students (Obrez et al.).

With the purpose to achieve better understanding and visualization of dental morphology, macromodels made of stone, resin or wax, are tools that have been proved to be efficient, both in this study and in others, as they are instruments that provide accurate anatomy (Gleiser).

These methods are important for motivating students, assisting the assimilation and memorization of anatomic details, and developing greater manual aptitude, which is necessary for professional practice (Siéssere et al.).

Therefore, the present study promoted higher performance and interest of undergraduate students at FOB-
USP, by developing an interdisciplinary methodology, involving manual activities based on theoretical knowledge, and aimed at clinical practice.

Furthermore, this study indicates that it is important to continue searching for alternative and integrative teaching techniques, which allow for developing both basic and professional sciences.

\section{CONCLUSIONS}

Teeth collars and macromodels assist the Dental Sculpture and Anatomy teaching, increasing the students' interest and developing their manual and cognitive skills.

\section{ACKNOWLEDGEMENTS}

The authors thank the professors and technicians (specially Mr. José Ari Gualberto Junqueira) of the Anatomy Department of the UNESP School of Dentistry/Araçatuba (São Paulo, Brazil), as well as the students of the Program "Teaching through Research" (Ensinar com Pesquisa) of the University of São Paulo Undergraduate Students Office of the Dean, who participated in the elaboration of the educational materials, namely: Milena Sierra Drumond da Costa, Mariana Giusti Stollai, Bárbara Cecília Tury Blumer and Isabela Zalotti Brandt.

BUCHAIM, R. L.; ANDREO, J. C.; RODRIGUES, A. C.; GONÇALVES, J. B. O.; DARÉ, L. R.; ROSA JÚNIOR, G. M.; BUCHAIM, D. V. \& DE OLIVEIRA, J. A. Enfoque multidisciplinario para la enseñanza de escultura y anatomía dental. Int. J. Morphol., 32(2):399-403, 2014.

RESUMEN: El propósito de la disciplina sobre escultura y anatomía de dientes es introducir a los estudiantes de pregrado para el estudio de las características anatómicas y morfológicas de la dentición humana permanente y primaria, a través de clases, libros y actividades cognitivas y psicomotoras. Esta disciplina se fundamenta en la enseñanza de conocimientos específicos necesarios para una educación más amplia, que implica la interdisciplinariedad como medio de intercambio de conocimientos entre diferentes áreas en odontología, y de esa forma, lograr una enseñanza profesional integral. Los estudiantes deben identificar la morfología dental a partir de dientes conservados, además de reproducir la morfología a través de modelos tridimensionales elaborados con bloques de yeso tipo piedra o cera. En este estudio, los autores describen el proceso para la producción de collares de dientes y macro modelos dentales hechos de yeso tipo piedra, su importancia y los beneficios de su utilización. El propósito del estudio fue incentivar la enseñanza de la escultura y anatomía dental a los estudiantes de pregrado de la Facultad de Odontología de Bauru, Universidad de São Paulo, a través de actividades que asocian la teoría, práctica y desarrollo de habilidades manuales.

PALABRAS CLAVE: Anatomía dental; Métodos de enseñanza; Estudiantes de pregrado; Ciencias básicas.

\section{REFERENCES}

Adams, A. B. The basic science curriculun problem in dental education: some causes and solutions. J. Dent. Educ., 40(4):230-2, 1976.
Allen, K. L. \& McAndrew, M. Integrating dental anatomy and biomaterials: an innovative use of composite resin. Gen. Dent., 52(2):132-3, 2004 
BUCHAIM, R. L.; ANDREO, J. C.; RODRIGUES, A. C.; GONÇALVES, J. B. O.; DARÉ, L. R.; ROSA JÚNIOR, G. M.; BUCHAIM, D. V. \& DE OLIVEIRA, J. A. Multidisciplinary approach in the teaching of dental sculpture and anatomy. Int. J. Morphol., 32(2):399-403, 2014.

Bogacki, R. E.; Best, A. \& Abbey, L. M. Equivalence study of a dental anatomy computer-assisted learning program. J. Dent. Educ., 68(8):867-71, 2004.

Brueckner, J. K. \& MacPherson, B. R. Benefits from peer teaching in the dental gross anatomy laboratory. Eur. J. Dent. Educ., 8(2):72-7, 2004.

Durham, J. A.; Brettell, S.; Summerside, C. \& McHanwell, S. Evaluation of a virtual anatomy course for clinical undergraduates. Eur. J. Dent. Educ., 13(2):100-9, 2009.

Fiehn, N. E. The basic science teaching experience in the Nordic countries. Eur. J. Dent. Educ., 2(3):115-23, 1998.

Gleiser, V. G. Dental anatomy: new method for teaching/learning. RGO Rev. Gaúcha Odontol., 40(5):339-41, 1992.

Jaffar, A. A. YouTube: An emerging tool in anatomy education. Anat. Sci. Educ., 5(3):158-64, 2012.

Jiffry, M. T.; Husain, R. \& Dias, A. P. A rationale for selecting suitable physiology topics for the basic sciences curriculum in dentistry. Med. Educ., 21(1):38-45, 1987.

Kataoka, K.; Kobayashi, S.; Sato, T.; Soji, T.; Shioda, S.; Torigoe, K.; Matsumura, J.; Hisano, S.; Yasuda, Y. \& Suzaki, E. Anatomy education in medical and dental schools in Japan. Kaibogaku Zasshi, 80(2):41-7, 2005.

Mitov, G.; Dillschneider, T.; Abed, M. R.; Hohenberg, G. \& Pospiech, P. Introducing and evaluating MorphoDent, a Webbased learning program in dental morphology. J. Dent. Educ., 74(10):1133-9, 2010.

Morita, M. C.; Kriger, L.; de Carvalho, A. C. P. \& Haddad, A. E. Implantação das Diretrizes Curriculares Nacionais em Odontologia. Maringá, Dental Press, 2007.

Obrez, A.; Briggs, C.; Buckman, J.; Goldstein, L.; Lamb, C. \& Knight, W. G. Teaching clinically relevant dental anatomy in the dental curriculum: description and assessment of an innovative module. J. Dent. Educ., 75(6):797-804, 2011.

Pao, Y. C.; Reinhardt, R. A.; Krejci, R. F. \& Taylor, D. T. Computer-graphics aided instruction of three-dimensional dental anatomy. J. Dent. Educ., 48(6):315-7, 1984.

Peck, D. \& Skandalakis, J. E. The anatomy of teaching and the teaching of anatomy. Am. Surg., 70(4):366-8, 2004.

Saxena, V.; Natarajan, P.; O'Sullivan, P. S. \& Jain, S. Effect of the use of instructional anatomy videos on student performance. Anat. Sci. Educ., 1(4):159-65, 2008.

Scheven, B. A. Perceived relevance of oral biology by dental students. Eur. J. Dent. Educ., 16(1):e64-72, 2012.

Siéssere, S.; Vitti, M.; de Sousa, L. G.; Semprini, M. \& Regallo,
S. C. Educational material of dental anatomy applied to study the morphology of permanent teeth. Braz. Dent. J., 15(3):23842, 2004

Stewart, B. L.; Ralph, W. J. \& Macmillan, C. H. Survey of dental practice/dental education in Victoria. Part I. Questionnaire/ general aspects. Aust. Dent. J., 34(6):563-70, 1989.

Valachovic, R. W. Making science clinically relevant. J. Dent. Educ., 61(5):434-6, 1997.

Correspondence to:

Rogério Leone Buchaim

University of São Paulo

School of Dentistry of Bauru

Department of Biological Sciences

Al. Octávio Pinheiro Brisola, 9-75, Cep: 17.012-901

Bauru - SP

BRAZIL

Email: rogerio@fob.usp.br

Received: 07-02-2013

Accepted: 08-02-2014 